University of Nebraska - Lincoln

DigitalCommons@University of Nebraska - Lincoln

\title{
Registration of N619 to N640 Grain Sorghum Lines with Waxy or Wild-Type Endosperm
}

\author{
M. K. Yerka \\ USDA-ARS, melinda.yerka@ars.usda.gov \\ J. J. Toy \\ USDA-ARS, John.Toy@ars.usda.gov \\ Deanna L. Funnell-Harris \\ USDA-ARS, Deanna.Funnell-Harris@ars.usda.gov \\ Scott E. Sattler \\ USDA-ARS, Scott.Sattler@ars.usda.gov \\ J. F. Pedersen \\ USDA-ARS, jpedersen1@unl.edu
}

Follow this and additional works at: https://digitalcommons.unl.edu/usdaarsfacpub

Yerka, M. K.; Toy, J. J.; Funnell-Harris, Deanna L.; Sattler, Scott E.; and Pedersen, J. F., "Registration of N619 to N640 Grain Sorghum Lines with Waxy or Wild-Type Endosperm" (2015). Publications from USDAARS / UNL Faculty. 1858.

https://digitalcommons.unl.edu/usdaarsfacpub/1858

This Article is brought to you for free and open access by the U.S. Department of Agriculture: Agricultural Research Service, Lincoln, Nebraska at DigitalCommons@University of Nebraska - Lincoln. It has been accepted for inclusion in Publications from USDA-ARS / UNL Faculty by an authorized administrator of DigitalCommons@University of Nebraska - Lincoln. 


\title{
Registration of N619 to N640 Grain Sorghum Lines with Waxy or Wild-Type Endosperm
}

\author{
M. K. Yerka, ${ }^{*}$ J. J. Toy, D. L. Funnell-Harris, S. E. Sattler, and J. F. Pedersen
}

\begin{abstract}
Sorghum [Sorghum bicolor (L.) Moench] lines N619 to N636 (A lines; Reg. No. GS-699 to GS-716, PI 670134 to PI 670151); N619 to N636 (B lines; Reg. No. GS-721 to GS-738, PI 671777 to PI 671794); and N637 to N640 (R lines; Reg. No. GS-717 to GS-720, PI 670152 to PI 670155) comprise nine pairs of seed parent $(A / B)$ lines, and two pairs of pollinator $(R)$ lines (11 pairs total) that are near-isogenic for waxy (low-amylose) or wildtype endosperm. Breeding work was conducted jointly by the USDA-ARS and the Agricultural Research Division, Institute of Agriculture and Natural Resources, University of Nebraska, and the lines were released in May 2014. Release of these lines makes available two different waxy $(w x)$ alleles $\left(w x^{a}\right.$ and $\left.w x^{b}\right)$ for development of grain sorghum as a source of lowamylose starch, whose end use is targeted to the ethanol and food industries. In particular, the release of $w x$ and wild-type near-isogenic pairs facilitates the evaluation of agronomic performance of $w x$ genotypes, and the release of both A/B and $\mathrm{R}$ lines facilitates the production of waxy grain hybrids.
\end{abstract}

This document is a U.S. government work and is not subject to copyright in the United States.

Copyright $\odot$ Crop Science Society of America. All rights reserved. No part of this periodical may be reproduced or transmitted in any form or by any means, electronic or mechanical, including photocopying, recording, or any information storage and retrieval system, without permission in writing from the publisher. Permission for printing and for reprinting the material contained herein has been obtained by the publisher.

Journal of Plant Registrations 9:249-253 (2015).

doi:10.3198/jpr2014.06.0043crgs

Received 20 June 2014. Accepted 7 Dec. 2014.

Registration by CSSA.

5585 Guilford Rd., Madison, WI 53711 USA

*Corresponding author (melinda.yerka@ars.usda.gov)
A MYLOSE content ranges from 20 to $30 \%$ of the starch within wild-type sorghum [Sorghum bicolor (L.) Moench] grain (Rooney and Serna-Saldivar, 2000). The $W a x y(W x)$ gene encodes granule-bound starch synthase (GBSS), which synthesizes the long chain starch amylose (Denyer et al., 2001). Loss-of-function mutations in $W x$ result in the endosperm having a waxy appearance and starch almost entirely composed of amylopectin (Denyer et al., 2001). The waxy phenotype has been recognized in sorghum since 1933 (Karper, 1933). Low-amylose starch is preferable to wild-type starch in the ethanol industry because amylose requires higher temperatures to paste than amylopectin; it increases viscosity and forms complexes with lipids and with itself, restricting access of hydrolytic enzymes to starch molecules and lengthening fermentation times (Sharma et al., 2007; Wang et al., 2008; Wang and Copeland, 2013). Low-amylose starch is further utilized in the food industry to improve the shelf life of breads, cakes, and pastes due to its stickiness and slower retrogradation (Wang and Copeland, 2013). Predominant crop sources of lowamylose starch include waxy corn (Zea mays L.), wheat (Triticum aestivum L.), rice (Oryza sativa L.), and potato (Solanum tuberosum L.) varieties. Sorghum requires less water than these crops except for wheat, so the opportunity exists to increase the supply of low-amylose starch to the ethanol and food industries through deployment of improved waxy varieties in drier regions of the world.

In sorghum, two waxy $(w x)$ mutations were identified in the $W x$ gene and characterized for the presence or absence of GBSS protein (Pedersen et al., 2005; Sattler et al., 2009). The $w x^{a}$ allele contains a large DNA insertion within the third exon of the gene, and both the GBSS protein and enzyme activity were undetectable in $w x^{a}$ grain (Pedersen et al., 2005; Sattler et al., 2009). The $w x^{b}$ allele contains a missense mutation that changes amino acid 268 from glutamine to histidine; although GBSS protein was detectable, GBSS enzyme activity was reduced

USDA-ARS, Grain, Forage, and Bioenergy Research Unit, 137 Keim Hall, East Campus, Univ. of Nebraska-Lincoln, Lincoln, NE 68583-0937. Mention of trade names or commercial products in this article is solely for the purpose of providing specific information and does not imply recommendation or endorsement by the U.S. Department of Agriculture. USDA is an equal opportunity provider and employer.

Abbreviations: GBSS, granule-bound starch synthase. 
by over $75 \%$ relative to wild-type in the grain (Pedersen et al., 2005; Sattler et al., 2009). While the effect of $w x^{a}$ relative to $w x^{b}$ on amylose content is unknown, the starch from both genotypes was identified as waxy following gelatinization and iodine staining, having a reddish-purple color compared with the deep blue color of starch containing amylose (Pedersen et al., 2004).

Interest in grain sorghum has increased since the USEPA announced in 2012 that ethanol produced from sorghum grain qualifies as an advanced biofuel (USEPA, 2012). However, $w x$ genotypes often have reduced grain yield relative to their nearisogenic wild-type counterparts (Rooney et al., 2005). The objective of this study was to develop near-isogenic pairs of waxy and wild-type lines to facilitate plant breeding and research on the agronomic performance of waxy varieties, as well as their end uses in the ethanol and food industries. Each $w x$ allele $\left(w x^{a}\right.$ and $\left.w x^{b}\right)$ was evaluated in multiple pedigrees and compared with their near-isogenic wild-type counterparts. Plant materials developed in this study with $A$ and $R$ fertility reactions facilitate future work evaluating waxy hybrids, including interallelic $\left(w x^{a}\right.$ $\left.\times w x^{b}\right)$ hybrids.

\section{Methods}

Sorghum near-isogenic lines N619 to N636 (A lines; Reg. No. GS-699 to GS-716, PI 670134 to PI 670151); N619 to N636 (B lines; Reg. No. GS-721 to GS-738, PI 671777 to PI 671794); and N637 to N640 (R lines; Reg. No. GS-717 to GS-720, PI 670152 to PI 670155) were developed by crossing various lines with genetic male sterility (ms3ms3), previously developed by the USDA-ARS in Lincoln (Pedersen et al., 1997), with waxy lines developed at Texas A\&M University (Table 1$). F_{1}$ plants from these original crosses were selfed to the $\mathrm{F}_{2}$ generation, then backcrossed with one of the parents to generate the $\mathrm{BC}_{1} \mathrm{~F}_{1}$ and then the $\mathrm{BC}_{1} \mathrm{~F}_{2}$, hereafter referred to as $\mathrm{F}_{1}$ and $\mathrm{F}_{2}$, respectively. Grain from individual $\mathrm{F}_{2}$ plants was subjected to iodine staining (Pedersen et al., 2004). Individuals segregating for $w x$ were selfed to generate the $\mathrm{F}_{3}$. A homozygous waxy and a homozygous wildtype plant were chosen among $\mathrm{F}_{3}$ individuals as counterparts to form a pair. These were selfed to the $\mathrm{F}_{7}$ generation for testing field agronomic performance. Nine pairs of B lines and two pairs of $R$ lines were developed using these methods from eleven original crosses. When $\mathrm{B}$ lines were in the $\mathrm{F}_{5}$ generation, $\mathrm{A}$ lines were developed by making crosses to the $A_{1}$ cytoplasm source ACK60, followed by backcrossing four times, to facilitate hybrid production. The result was nine pairs of near-isogenic $\mathrm{A} / \mathrm{B}$ lines, one $\mathrm{A} / \mathrm{B}$ line waxy and its counterpart $\mathrm{A} / \mathrm{B}$ line wild-type, from each of the nine original $\mathrm{B}$ line crosses.

The $\mathrm{F}_{7} \mathrm{~B}$ and $\mathrm{R}$ lines were tested for field agronomic performance at the University of Nebraska Field Laboratory at Lincoln, NE, and at the University of Nebraska Agricultural Research and Development Center near Mead, NE, in 2009. The wild-type cultivars B 'Wheatland' (Brown et al., 1936) and R 'Tx430' (Miller, 1984), common hybrid parents, were included for comparison. Each plot consisted of two 7.6-m rows spaced $76 \mathrm{~cm}$ apart with 120 seeds per row delivered by a precision vacuum planter in the third week of May. For both locations, nitrogen fertilizer was applied at $112 \mathrm{~kg} \mathrm{ha}^{-1}$ before planting. Atrazine [6-chloro-n-ethyl- $N^{\prime}$ (1-methylethyl)-1,3,5triazine-2,4,diamine] was applied at $1.12 \mathrm{~kg} \mathrm{ha}^{-1}$ immediately after planting, followed by an application of quinclorac (3,7-dichloro-8-quinolinecarboxylic acid) and atrazine at 0.37 and $0.56 \mathrm{~kg} \mathrm{ha}^{-1}$, respectively, $5 \mathrm{wk}$ after planting at Lincoln and $4 \mathrm{wk}$ after planting at Mead. Supplemental irrigation $(3.8 \mathrm{~cm})$ was applied at Mead via overhead sprinklers on 6

Table 1. Pedigree, fertility reaction, endosperm type, and waxy source of the sorghum near-isogenic lines.

\begin{tabular}{|c|c|c|c|c|c|}
\hline Entry & Pair & Pedigreet & Fertility reaction $\neq$ & Endosperm & waxy source \\
\hline N619 & 1 & $\mathrm{~F}_{8}\left[\left(\mathrm{~F}_{2} \mathrm{BN} 226 m s 3 m s 3 \times \mathrm{B} 9307\right) / \mathrm{B} 9307 \mathrm{BC}\right]$ & $A / B$ & waxy & $w x^{b}$ B9307 \\
\hline N620 & 1 & $\mathrm{~F}_{8}\left[\left(\mathrm{~F}_{2} \mathrm{BN} 226 \mathrm{~ms} 3 m s 3 \times \mathrm{B} 9307\right) / \mathrm{B} 9307 \mathrm{BC}_{1}\right]$ & $A / B$ & wild-type & \\
\hline N621 & 2 & $\mathrm{~F}_{8}\left[\left(\mathrm{~F}_{2} \mathrm{BN} 230 \mathrm{~ms} 3 \mathrm{~ms} 3 \times \mathrm{B} 94 \mathrm{C} 274\right) / \mathrm{B} 94 \mathrm{C} 274 \mathrm{BC}_{1}\right]$ & $A / B$ & waxy & $w x^{a}$ B94C274 \\
\hline N622 & 2 & $\mathrm{~F}_{8}\left[\left(\mathrm{~F}_{2} \mathrm{BN} 230 \mathrm{~ms} 3 \mathrm{~ms} 3 \times \mathrm{B} 94 \mathrm{C} 274\right) / \mathrm{B} 94 \mathrm{C} 274 \mathrm{BC}_{1}\right]$ & $A / B$ & wild-type & \\
\hline N623 & 3 & $\mathrm{~F}_{8}\left[\left(\mathrm{~F}_{2} \mathrm{BN} 230 \mathrm{~ms} 3 \mathrm{~ms} 3 \times \mathrm{B} 94 \mathrm{C} 274\right) / \mathrm{BT} \times 631 \mathrm{BC}_{1}\right]$ & $A / B$ & waxy & $w x^{a}$ B94C274 \\
\hline N624 & 3 & $\mathrm{~F}_{8}\left[\left(\mathrm{~F}_{2} \mathrm{BN} 230 \mathrm{~ms} 3 \mathrm{~ms} 3 \times \mathrm{B} 94 \mathrm{C} 274\right) / \mathrm{BT} \times 631 \mathrm{BC}_{1}\right]$ & $A / B$ & wild-type & \\
\hline N625 & 4 & $\mathrm{~F}_{8}\left[\left(\mathrm{~F}_{2} \mathrm{BN} 241 m s 3 m s 3 \times \mathrm{B} 9307\right) / \mathrm{B} 9307 \mathrm{BC}_{1}\right]$ & $A / B$ & waxy & $w x^{b} \mathrm{~B} 9307$ \\
\hline N626 & 4 & $\mathrm{~F}_{8}\left[\left(\mathrm{~F}_{2} \mathrm{BN} 241 m s 3 m s 3 \times \mathrm{B} 9307\right) / \mathrm{B} 9307 \mathrm{BC}_{1}\right]$ & $A / B$ & wild-type & \\
\hline N627 & 5 & $\mathrm{~F}_{8}\left[\left(\mathrm{~F}_{2} \mathrm{BN} 224 m s 3 m s 3 \times \mathrm{BT} \times \mathrm{ARG}-1\right) / \mathrm{BT} \times \mathrm{ARG}-1 \mathrm{BC} \mathrm{C}_{1}\right]$ & $A / B$ & waxy & $w x^{b}$ BTXARG-1 \\
\hline N628 & 5 & $\mathrm{~F}_{8}\left[\left(\mathrm{~F}_{2} \mathrm{BN} 224 m s 3 m s 3 \times \mathrm{BT} \times \mathrm{ARG}-1\right) / \mathrm{BT} \times \mathrm{ARG}-1 \mathrm{BC}{ }_{1}\right]$ & $\mathrm{A} / \mathrm{B}$ & wild-type & \\
\hline N629 & 6 & $\mathrm{~F}_{8}\left[\left(\mathrm{~F}_{2} \mathrm{BN} 224 m s 3 m s 3 \times \mathrm{B} 94 \mathrm{C} 274\right) / \mathrm{B} 94 \mathrm{C} 274 \mathrm{BC}_{1}\right]$ & $A / B$ & waxy & $w x^{a}$ B94C274 \\
\hline N630 & 6 & $\mathrm{~F}_{8}\left[\left(\mathrm{~F}_{2} \mathrm{BN} 224 m s 3 m s 3 \times \mathrm{B} 94 \mathrm{C} 274\right) / \mathrm{B} 94 \mathrm{C} 274 \mathrm{BC}\right]$ & $A / B$ & wild-type & \\
\hline N631 & 7 & $\mathrm{~F}_{8}\left[\left(\mathrm{~F}_{2} \mathrm{BN} 227 m s 3 m s 3 \times \mathrm{BT} x \mathrm{ARG}-1\right) / \mathrm{BT} \times \mathrm{ARG}-1 \mathrm{BC}_{1}\right]$ & $A / B$ & waxy & $w x^{b}$ BTxARG-1 \\
\hline N632 & 7 & $\mathrm{~F}_{8}\left[\left(\mathrm{~F}_{2} \mathrm{BN} 227 m s 3 m s 3 \times \mathrm{BT} x \mathrm{ARG}-1\right) / \mathrm{BT} \times \mathrm{ARG}-1 \mathrm{BC}\right]$ & $A / B$ & wild-type & \\
\hline N633 & 8 & $\mathrm{~F}_{8}\left[\left(\mathrm{~F}_{2} \mathrm{BN} 231 \mathrm{~ms} 3 \mathrm{~ms} 3 \times \mathrm{BT}\right.\right.$ ARG-1)/BTxARG-1 BC $]$ & $A / B$ & waxy & $w x^{b}$ BTXARG-1 \\
\hline N634 & 8 & $\mathrm{~F}_{8}\left[\left(\mathrm{~F}_{2} \mathrm{BN} 231 \mathrm{~ms} 3 \mathrm{~ms} 3 \times \mathrm{BT} \times \mathrm{ARG}-1\right) / \mathrm{BT} x \mathrm{ARG}-1 \mathrm{BC}{ }_{1}\right]$ & $\mathrm{A} / \mathrm{B}$ & wild-type & \\
\hline N635 & 9 & $\mathrm{~F}_{8}\left[\left(\mathrm{~F}_{2} \mathrm{BN} 232 \mathrm{~ms} 3 m s 3 \times \mathrm{B} 9307\right) / \mathrm{B} 9307 \mathrm{BC}_{1}\right]$ & $\mathrm{A} / \mathrm{B}$ & waxy & $w x^{b} \mathrm{~B} 9307$ \\
\hline N636 & 9 & $\mathrm{~F}_{8}\left[\left(\mathrm{~F}_{2} \mathrm{BN} 232 \mathrm{~ms} 3 m s 3 \times \mathrm{B} 9307\right) / \mathrm{B} 9307 \mathrm{BC}_{1}\right]$ & $A / B$ & wild-type & \\
\hline N637 & 10 & $\mathrm{~F}_{8}\left[\left(\mathrm{~F}_{2} \mathrm{RN} 228 m s 3 m s 3 \times \mathrm{R} 94 \mathrm{C} 289\right) / \mathrm{RSC} 110-9 \mathrm{BC}_{1}\right]$ & $\mathrm{R}$ & waxy & $w x^{a}$ R94C289 \\
\hline N638 & 10 & $\mathrm{~F}_{8}\left[\left(\mathrm{~F}_{2} \mathrm{RN} 228 \mathrm{~ms} 3 \mathrm{~ms} 3 \times \mathrm{R} 94 \mathrm{C} 289\right) / \mathrm{RSC} 110-9 \mathrm{BC}_{1}\right]$ & $\mathrm{R}$ & wild-type & \\
\hline N639 & 11 & $\mathrm{~F}_{8}\left[\left(\mathrm{~F}_{2} \mathrm{RN} 229 \mathrm{~ms} 3 \mathrm{~ms} 3 \times \mathrm{R} 94 \mathrm{C} 289\right) / \mathrm{R} 94 \mathrm{C} 289 \mathrm{BC}_{1}\right]$ & $\mathrm{R}$ & waxy & $w x^{a} \mathrm{R} 94 \mathrm{C} 289$ \\
\hline N640 & 11 & $\mathrm{~F}_{8}\left[\left(\mathrm{~F}_{2} \mathrm{RN} 229 m s 3 m s 3 \times \mathrm{R} 94 \mathrm{C} 289\right) / \mathrm{R} 94 \mathrm{C} 289 \mathrm{BC}_{1}\right]$ & $\mathrm{R}$ & wild-type & \\
\hline
\end{tabular}

† ms3ms3 lines are from Pedersen et al. (1997).

₹ Fertility reaction to $A$ cytoplasmic male-sterile cytoplasm: $A / B=$ male-sterile/maintainer pair, $R=$ fertility restorer. 
and 29 August. No supplemental irrigation was applied at Lincoln. Field emergence was recorded 4 wk after planting at Lincoln and 5 wk after planting at Mead. Days to $50 \%$ anthesis was recorded. Height was measured at maturity. Grain yield was adjusted to $145 \mathrm{~g} \mathrm{~kg}^{-1}$ water content before analysis. Test weight was recorded. The experimental design was a randomized complete block with four replicates at each location. Entry, endosperm type (waxy vs. wild-type), Waxy allele $\left(W x, w x^{a}, w x^{b}\right)$, and environment (field location) were treated as fixed effects and replicate was a random effect. Data were subjected to ANOVA in the PROC MIXED procedure of SAS software, version 9.3 (SAS Institute, 2012). Withinpair least-squares means of waxy and wild-type counterparts were separated with a two-sample $t$ test. Two-sample $t$ tests were also used to compare least-squares means from $\mathrm{B}$ line entries to BWheatland, and R line entries to RTx430. The homogeneity of variance assumption of ANOVA was tested in PROC GLM with a Levene's test. The normality assumption of ANOVA was tested in PROC UNIVARIATE with a Shapiro-Wilke test and analysis of Q-Q plots. All tests were performed at the $P=0.05$ level of significance. Location $\times$ treatment interactions were insignificant for all statistical tests so that data were pooled across both environments.

\section{Characteristics}

Descriptive characteristics of waxy and wild-type nearisogenic line pairs of grain sorghum are given in Table 2. All line pairs have a white caryopsis, no tannin-containing testa layer, no awns, and juicy culms. The line pairs have tan plant color, except that N627 and N628 (Pair 5) and N637 and N638 (Pair 10) have purple plant color. The line pairs are combine-height and photoperiod-insensitive, with $\mathrm{A} / \mathrm{B}$ and $\mathrm{R}$ fertility reactions to
A cytoplasmic male-sterile cytoplasm that make them suitable for hybrid production and evaluation.

Least-squares means for field emergence, days to $50 \%$ anthesis, height, grain yield, and test weight are presented in Table 3. No overall waxy effect was observed in field emergence, days to $50 \%$ anthesis, height, or test weight among entries. However, the mean grain yield of all wild-type near-isogenic lines was greater than that of all waxy lines, $7825 \pm 104$ compared with $7096 \pm 114 \mathrm{~kg} \mathrm{ha}^{-1}(P<0.001)$, respectively. Grain yield of four waxy B lines (N627, N629, N631, and N633) did not differ statistically from that of their wild-type counterparts. Waxy B line yield was generally lower than that of BWheatland $\left(7936 \pm 322 \mathrm{~kg} \mathrm{ha}^{-1}\right)$, with the exception of N621 and N633 (7809 and $7376 \pm 322 \mathrm{~kg} \mathrm{ha}^{-1}$, respectively), which did not significantly differ from BWheatland. No yield drag was observed in the two $\mathrm{R}$ line pairs evaluated. Grain yield of waxy R line N639 (7782 $\left.\pm 322 \mathrm{~kg} \mathrm{ha}^{-1}\right)$ was not statistically different from that of its wild-type counterpart $\mathrm{R}$ line N640 and RTx430 (7735 and $7045 \pm 322 \mathrm{~kg} \mathrm{ha}^{-1}$, respectively). R line N637 had the highest yield (8856 \pm 322 $\mathrm{kg} \mathrm{ha}^{-1}$ ) of all waxy lines evaluated, exceeding that of its wildtype counterpart, N638 (7747 $\left.\pm 322 \mathrm{~kg} \mathrm{ha}^{-1}\right)$ and RTx430. Thus, B lines N627, N629, N631, and N633 and R lines N637 and N639 did not demonstrate the yield drag often associated with waxy genotypes.

An allele effect was observed for grain yield, which was highest for WT lines $\left(7777 \pm 104 \mathrm{~kg} \mathrm{ha}^{-1}\right)$, intermediate for $w x^{a}$ lines $\left(7591 \pm 152 \mathrm{~kg} \mathrm{ha}^{-1}\right)$, and lowest for $w x^{b}$ lines $(6580 \pm$ $\left.155 \mathrm{~kg} \mathrm{ha}^{-1}\right)$. Average $w x^{a}$ yield did not statistically differ from that of WT, but both $w x^{a}$ and WT line yields were greater than that of $w x^{b}$ lines. Yield differences were not associated with differences in test weight, as no allele effect on test weight was observed. These results are similar to our previous research (Pedersen and Toy, unpublished data), which showed a grain

Table 2. Descriptive characteristics of waxy and wild-type near-isogenic line pairs of grain sorghum.

\begin{tabular}{|c|c|c|c|c|c|c|c|}
\hline Entry & Pair & Endosperm & Plant color & Caryopsis color & Testa & Awns & Culms \\
\hline N619 & 1 & waxy & $\tan$ & white & no & no & juicy \\
\hline N620 & 1 & wild-type & $\tan$ & white & no & no & juicy \\
\hline N621 & 2 & waxy & $\tan$ & white & no & no & juicy \\
\hline N622 & 2 & wild-type & $\tan$ & white & no & no & juicy \\
\hline N623 & 3 & waxy & $\tan$ & white & no & no & juicy \\
\hline N624 & 3 & wild-type & $\tan$ & white & no & no & juicy \\
\hline N625 & 4 & waxy & $\tan$ & white & no & no & juicy \\
\hline N626 & 4 & wild-type & $\tan$ & white & no & no & juicy \\
\hline N627 & 5 & waxy & purple & white & no & no & juicy \\
\hline N628 & 5 & wild-type & purple & white & no & no & juicy \\
\hline N629 & 6 & waxy & $\tan$ & white & no & no & juicy \\
\hline N630 & 6 & wild-type & $\tan$ & white & no & no & juicy \\
\hline N631 & 7 & waxy & $\tan$ & white & no & no & juicy \\
\hline N632 & 7 & wild-type & $\tan$ & white & no & no & juicy \\
\hline N633 & 8 & waxy & $\tan$ & white & no & no & juicy \\
\hline N634 & 8 & wild-type & $\tan$ & white & no & no & juicy \\
\hline N635 & 9 & waxy & $\tan$ & white & no & no & juicy \\
\hline N636 & 9 & wild-type & $\tan$ & white & no & no & juicy \\
\hline N637 & 10 & waxy & purple & white & no & no & juicy \\
\hline N638 & 10 & wild-type & purple & white & no & no & juicy \\
\hline N639 & 11 & waxy & $\tan$ & white & no & no & juicy \\
\hline N640 & 11 & wild-type & $\tan$ & white & no & no & juicy \\
\hline
\end{tabular}


Table 3. Grain yield and agronomic performance of waxy and wild-type near-isogenic line pairs of grain sorghum. BWheatland and RTx430 were included for comparison.

\begin{tabular}{|c|c|c|c|c|c|c|c|}
\hline Entry† & Pair & Endosperm & Emergence & $\begin{array}{c}\text { Days to } 50 \% \\
\text { anthesis }\end{array}$ & Height & Grain yield‡ & Test weight \\
\hline & & & plants $\mathrm{m}^{-1}$ & & $\mathrm{~cm}$ & $\mathrm{~kg} \mathrm{ha}^{-1}$ & $\mathrm{~kg} \mathrm{hL}^{-1}$ \\
\hline BN619 & 1 & waxy & 12 & $79 \S$ & 121 & 5969 & 73 \\
\hline BN620 & 1 & wild-type & 12 & 81 & 113 & 7850 & 71 \\
\hline BN621 & 2 & waxy & 16 & 82 & 141 & 7809 & 67 \\
\hline BN622 & 2 & wild-type & 15 & 82 & 149 & 8888 & 71 \\
\hline BN623 & 3 & waxy & 14 & 81 & 150 & 7038 & 73 \\
\hline BN624 & 3 & wild-type & 16 & 80 & 154 & 8873 & 74 \\
\hline BN625 & 4 & waxy & 14 & 83 & 127 & 6796 & 72 \\
\hline BN626 & 4 & wild-type & 17 & 84 & 125 & 7720 & 74 \\
\hline BN627 & 5 & waxy & 16 & 80 & 128 & 6138 & 73 \\
\hline BN628 & 5 & wild-type & 15 & 79 & 129 & 6976 & 71 \\
\hline BN629 & 6 & waxy & 16 & 81 & 152 & 7028 & 71 \\
\hline BN630 & 6 & wild-type & 15 & 80 & 149 & 7531 & 72 \\
\hline BN631 & 7 & waxy & 14 & 82 & 116 & 7003 & 72 \\
\hline BN632 & 7 & wild-type & 14 & 81 & 119 & 7589 & 76 \\
\hline BN633 & 8 & waxy & 16 & 81 & 130 & 7376 & 72 \\
\hline BN634 & 8 & wild-type & 14 & 80 & 131 & 8293 & 76 \\
\hline BN635 & 9 & waxy & 15 & 81 & 129 & 6229 & 73 \\
\hline BN636 & 9 & wild-type & 17 & 79 & 135 & 7304 & 74 \\
\hline RN637 & 10 & waxy & 14 & 83 & 119 & 8856 & 77 \\
\hline RN638 & 10 & wild-type & 13 & 83 & 131 & 7747 & 76 \\
\hline RN639 & 11 & waxy & 16 & 83 & 129 & 7782 & 76 \\
\hline RN640 & 11 & wild-type & 14 & 84 & 121 & 7735 & 76 \\
\hline BWheatland & & wild-type & 17 & 81 & 106 & 7936 & 71 \\
\hline RTx430 & & wild-type & 14 & 83 & 121 & 7045 & 66 \\
\hline $\mathrm{LSD}_{0.05}$ & & & 3 & 2 & 5 & 1236 & 3.4 \\
\hline
\end{tabular}

$\dagger \mathrm{B}=\mathrm{B}$ line; $\mathrm{R}=\mathrm{R}$ line.

‡ Grain yield was adjusted to $145 \mathrm{~g} \mathrm{~kg}^{-1}$ moisture before analysis.

$\S$ Boldface type denotes means within pair that differ, based on two-sample $t$ tests at $P=0.05$. Data were pooled across two environments: Lincoln and Mead, NE (2009).

yield reduction of $2.7 \%$ in $w x^{a} \mathrm{BT} \times 630$ and $8.1 \%$ in $w x^{b} \mathrm{~B} 9307$ relative to the wild-type (Sattler et al., 2009). The exact cause of greater yield reductions in $w x^{b}$ genotypes remains unclear. Further work testing the effects of $w x^{a}$ and $w x^{b}$ alleles in near-isogenic backgrounds, as well as the new alleles recently reported in Kawahigashi et al. (2013) and Lu et al. (2013), will be of interest to researchers seeking to identify the best combinations of alleles and pedigrees for improved agronomic performance and end use of waxy sorghum varieties for the ethanol and food industries.

\section{Conclusions}

Release of lines N619 to N640 makes available two different waxy alleles of sorghum, $w x^{a}$ and $w x^{b}$, for comparison to $W x$ counterparts in near-isogenic backgrounds, and for breeding of additional adapted waxy sorghum breeding lines and hybrids. The release provides potential sources of low-amylose starch genetic stocks for breeding applications in drier regions of the world. $W x, w x^{a}$, and $w x^{b}$ alleles had no overall effect on field emergence, days to $50 \%$ anthesis, height, or test weight among entries. Grain yields of B lines N627, N629, N631, and N633 and R line N639 were similar to those of their near-isogenic wild-type counterparts. R line N637 had the highest grain yield among all waxy lines evaluated.

\section{Availability}

Seed of these sorghum genetic stocks will be maintained and distributed by the USDA-ARS, Grain, Forage, and Bioenergy Research Unit, 137 Keim Hall, East Campus, University of Nebraska, Lincoln, NE 68583-0937, and will be provided without cost to each applicant on written request. Genetic materials of this release have been deposited in the National Plant Germplasm System, where it will be immediately available for research purposes, including development and commercialization of new cultivars. It is requested that appropriate recognition be made if these lines contribute to the development of new breeding materials.

\section{Acknowledgments}

We thank Dr. William Rooney of Texas A\&M University for providing the original waxy source lines used in the development of these lines. We thank Patrick O'Neill for his technical assistance with statistical analysis of data presented in this manuscript.

\section{References}

Brown, H.B., J.A. Clark, E.F. Gaines, H.K. Hayes, W.J. Morse, J.H. Parker, T.R. Stanton, G.H. Stringfield, and M.A. McCall. 1936. Varietal standardization and registration. J. Am. Soc. Agron. 28:1027.

Denyer, K., P. Johnson, S. Zeeman, and A.M. Smith. 2001. The control of amylose synthesis. J. Plant Physiol. 158:479-487. doi:10.1078/0176-161700360 
Karper, R.E. 1933. Inheritance of waxy endosperm in sorghum. J. Hered. 24:257-262.

Kawahigashi, H., M. Oshima, T. Nishikawa, H. Okuizumi, S. Kasuga, and J. Yonemaru. 2013. A novel waxy allele in sorghum landraces in East Asia. Plant Breed. 132:305-310. doi:10.1111/pbr.12054

Lu, Y.G., G.L. Zhao, Y. Li, J. Fan, G.X. Ding, J.Q. Zhao, X.L. Ni, Y.J. Xu, and W.M. Wang. 2013. Identification of two novel waxy alleles and development of their molecular markers in sorghum. Genome 56:283288. doi:10.1139/gen-2013-0047

Miller, F.R. 1984. Registration of RTx430 sorghum parental line. Crop Sci. 24:1224. doi:10.2135/cropsci1984.0011183X002400060074x

Pedersen, J.F., S.R. Bean, D.L. Funnell, and R.A. Graybosch. 2004. Rapid iodine staining techniques for identifying the waxy phenotype in sorghum grain and waxy genotype in sorghum pollen. Crop Sci. 44:764-767. doi: $10.2135 /$ cropsci2004.7640

Pedersen, J.F., S.R. Bean, R.A. Graybosch, S.H. Park, and M. Tilley. 2005. Characterization of waxy grain sorghum lines in relation to granule-bound starch synthase. Euphytica 144:151-156. doi:10.1007/s10681-005-5298-5

Pedersen, J.F., J.J. Toy, and B.E. Johnson. 1997. Registration of 21 sorghum genetic stocks with ms3ms3. Crop Sci. 37:1410-1411. doi:10.2135/cropsci 1997.0011183X003700040098x

Rooney, W.L., S. Aydin, and L.C. Kuhlman. 2005. Assessing the relationship between endosperm type and grain yield potential in sorghum (Sorghum bicolor L. Moench). Field Crops Res. 91:199-205. doi:10.1016/j. fcr.2004.07.011
Rooney, W.L., and S.O. Serna-Saldivar. 2000. Sorghum. In: K. Kulp and J. G. Ponte, Jr., editors, Handbook of cereal science and technology. 2nd ed. Marcel Dekker: New York. p. 149-176.

SAS Institute. 2012. The SAS system for Windows. V. 9.3. SAS Inst., Cary, NC.

Sattler, S.E., J. Singh, E.J. Haas, L. Guo, G. Sarath, and J.F. Pedersen. 2009. Two distinct waxy alleles impact the granule-bound starch synthase in sorghum. Mol. Breed. 24:349-359. doi:10.1007/s11032-009-9296-5

Sharma, V., K.D. Rausch, M.E. Tumbleson, and V. Singh. 2007. Comparison between granular starch hydrolyzing enzyme and conventional enzymes for ethanol production from maize starch with different amylose:amylopectin ratios. Starke 59:549-556. doi:10.1002/star.200700631

USEPA. 2012. Supplemental determination for the renewable fuels produced under the final RFS2 program from grain sorghum. Fed. Regist. 77:7459274607. https://federalregister.gov/a/2012-30100.

Wang, D., S.R. Bean, J. McLaren, P. Seib, R. Madl, M. Tuinstra, Y. Shi, M. Lenz, X. Wu, and R. Zhao. 2008. Grain sorghum is a viable feedstock for ethanol production. J. Ind. Microbiol. Biotechnol. 35:313-320. doi:10.1007/s10295-008-0313-1

Wang, S., and L. Copeland. 2013. Molecular disassembly of starch granules during gelatinization and its effect on starch digestibility: A review. Food Funct. 4:1564-1580. doi:10.1039/c3fo60258c 